\title{
Impact of UV-B radiation on microalgae and bacteria: a mesocosm study with computer modulated UV-B radiation addition
}

\author{
Sten-Åke Wängberg* ${ }^{*}$ Angela Wulff, Claes Nilsson, Ulrica Stagell \\ Botanical Institute, Göteborg University, PO Box 461, 40530 Göteborg, Sweden
}

\begin{abstract}
Effects of ambient and enhanced UV-B radiation (UVBR) on marine microbial plankton communities were assessed in a model ecosystem at Kristineberg Marine Research Station (KMRS) on the Swedish west coast. The system consisted of 16 aquaria (40 l) filled with surface seawater and semicontinuously run by replacing $10 \mathrm{l}$ of their contents with filtered seawater twice a day. The aquaria were placed outdoors and the ambient solar radiation was reduced by $70 \%$ using neutral screens. Four different levels of UVBR were applied, each in 4 replicates: nothing, ambient, ambient $+10 \%$ and ambient $+20 \%$. The enhanced UVBR was supplied by fluorescent tubes whose intensity was modulated by the ambient radiation to give a constant percentage increase. Variables measured were nutrients $(\mathrm{N}, \mathrm{P}, \mathrm{Si})$, composition of phytoplankton species and pigments, bacterial and primary productivity, and bacterial cell numbers. Statistically significant UVBR effects were found for carbon allocation, size distribution of primary productivity and phytoplankton species composition. It was also found that UVBR exposure during the development of the phytoplankton communities increased their sensitivity to UVBR in short-term carbon dioxide fixation measurements. We propose that this was due to an adaptation of the community to UVBR, including an increased production of components within the photosynthetic apparatus damaged by UVBR. The UVBR had no significant effect on the total biomass of phytoplankton and bacteria.
\end{abstract}

KEY WORDS: UV-B radiation · Primary production · Marine microbial plankton · Plankton · Pigment

\section{INTRODUCTION}

The effects that increased UV-B radiation (UVBR; 280 to $320 \mathrm{~nm}$ ) have on marine microbial ecosystems are still unclear. Several observations have shown that UVBR negatively affects major ecological processes such as carbon dioxide fixation, bacterial growth and nutrient turnover (e.g., Vincent \& Roy 1993, Wängberg et al. 1996a, Davidson 1998). Within phytoplankton communities, a large species-specific UVBR sensitivity has been shown, and enhanced UVBR has been found to change the species composition (Worrest et al. 1981, Wängberg et al. 1996b). UVBR can also photolyse refractory DOM thereby releasing carbon and nutrients (Wetzel et al. 1995, Bushaw et al. 1996) leading to increased biological activity (Karentz et al. 1994,

*E-mail: swa@fysbot.gu.se
Wängberg et al. 1999, Gustavson et al. 2000). Algae and bacteria are also capable of avoiding the negative effects of UVBR by producing screening pigments, quenching toxic photoproducts or increasing their repair capacity (Mitchell \& Karentz 1993, Karentz 1994, Davidson 1998).

To understand the effects UVBR has on plankton communities demands long-term experiments which integrating negative, positive and adaptive processes. Such experiments are unfortunately rare (Wängberg \& Selmer 1997 and references therein). UVBR effects on community level are complex and UVBR has been shown to stimulate the microalgae through either reduction of grazers (Bothwell et al. 1994) or the photolysis effect on DOM (Wängberg et al. 1999). Furthermore, time-scales are important when designing ecologically relevant experiments. Effects on the structure of algal communities are predominantly found early in 
the experiments (Cabrera et al. 1997, Keller et al. 1997, Wulff et al. 2000) when the succession is high. Smaller effects observed later in the experiments can be due to, for example, competition for resources (nutrient or space) or UVBR adaptation of the community (Laurion et al. 1998, Odmark et al. 1998).

Not only the consequences on biomass and productivity are important when analysing UVBR effects in microbial communities; other important factors include UVBR-mediated changes in size distribution within the plankton community and carbon allocation to different biomolecules. Both of these factors are indicative of the status of the community and are important for the value of phytoplankton as prey. It has previously been assumed that larger cells are generally less sensitive to UVBR than smaller cells (Karentz et al. 1991, Bothwell et al. 1993). Wängberg et al. (1996b) found that the smaller algae were more sensitive if the analysis was reduced to a single class of diatoms (Centrales), but not when the whole community was analysed. In the study of Laurion et al. (1998) the fraction of total chlorophyll a (chl a) in picoplankton increased significantly when the community was shielded from UVBR. Recently Mostajir et al. (1999) found that UVBR reduced the number of large (5 to $20 \mu \mathrm{m}$ ) but not small $(<5 \mu \mathrm{m})$ phytoplankton, which they assumed was due to UVBR-induced changes in grazing pressure (reduction in ciliates that graze on small phytoplankton).

Even if UVBR does not reduce the primary productivity, it has been shown to affect the allocation of fixed carbon. Arts \& Rai (1997) showed that the UVBR effects on carbon allocation are species-specific. Furthermore, Wängberg et al. (1998) found that the fraction allocated to polysaccharides increased when the fraction allocated to low molecular weight (LMW) compounds decreased during the development of plankton communities under UVBR exposure. In a diatom-dominated microbenthic community the fractions allocated to proteins and lipids increased while the fractions allocated to polysaccharides and LMW compounds decreased after UVBR exposure (Sundbäck et al. 1997).

A complication when comparing different UVBR experiments is the discrepancy in UVBR levels used. In most UVBR experiments the only treatment is that the ambient UVBR is excluded (Bothwell et al. 1993, Cabrera et al. 1997, Wulff et al. 1999), thus showing effects of ambient UVBR rather than consequences of increased UVBR following a reduction of the stratospheric ozone layer. When the UVBR is enhanced artificially, a fixed light intensity is generally added for a few hours per day (Worrest et al. 1981, Keller et al. 1997, Laurion et al. 1998, Odmark et al. 1998, Mostajir et al. 1999, Wängberg et al. 1999). This can mimic an increase of the UV-B dose $\mathrm{d}^{-1}$ following a specific reduction of the stratospheric ozone layer. There are, however, substantial natural variations in ambient radiation due to, for instance, clouds and time of day. As a consequence, a fixed addition of UVBR can result in strong differences in the relative increase depending on the time of day and the actual weather situation. This can produce biased results, as UVBR effects are dependent on the ratios between UV-B, UV-A and PAR (Karentz 1994, Prezelin et al. 1994, Franklin \& Forster 1997, Laurion et al. 1998). Moroz et al. (1999) recently showed that the motility of Nitzschia linearis was unaffected on sunny but not on overcast days when exposed to the same UVBR intensities.

Therefore, the best experimental approach is to modulate the UVBR enhancement so that a constant fraction of the incident surface irradiance is achieved. Such systems have been used by terrestrial ecologists to achieve realistic simulations of ozone depletion (e.g., McLoed 1997) and were used in the present study to investigate UVBR effects on a marine plankton model ecosystem. The exposure system was also used for an experiment with benthic microbial communities that was run simultaneously with the experiment presented here (Wulff et al. 2000).

The experiment was specifically designed to study the effects of ecologically relevant UVBR levels on growing microbial communities and to determine whether this affects important functional and structural variables: primary and bacterial productivity, composition of the phytoplankton community, and concentration of nutrients and DOC. Special attention was paid to the carbon allocation and carbon fixation, which was fractionated in different size classes and measured at different times of the day.

\section{MATERIAL AND METHODS}

Location and weather conditions. The experiment was performed at Kristineberg Marine Research Station (KMRS) on the Swedish west coast $\left(58.2^{\circ} \mathrm{N}\right.$, $13.4^{\circ} \mathrm{E}$ ) for $10 \mathrm{~d}$, from 3 to 13 June 1997 . The weather during the whole experiment was sunny. The incoming PAR had typical values of ca $1800 \mu \mathrm{mol}$ photons $\mathrm{m}^{-2} \mathrm{~s}^{-1}$ (midday). Downwelling UVBR was measured between 07:00 and 17:00 h using a cosine-corrected sensor (SUL 240, International Light Inc., Newburyport, MA, USA) calibrated against a spectroradiometer (OL754, Optronic Laboratories, Orlando, FL, USA). The maximal UV-B irradiation on each day was, on average, $0.84 \pm 0.11 \mathrm{~W}$ $\mathrm{m}^{-2}$ and the mean UVBR dose $\mathrm{d}^{-1}$ was $3.96 \pm 0.52 \mathrm{~kJ} \mathrm{~m}^{-2}$ (mean $\pm \mathrm{SD}$ ). The stratospheric ozone layer during the experiment was on average 343 Dobson Unit (DU) \pm 4 (Total Ozone Mapping Instruments [TOMS] data).

Experimental set up. The outdoor model ecosystem consisted of 16 aquaria (40 1: $28.5 \times 28.5 \times 49 \mathrm{~cm}$ [length 
$\times$ width $\times$ height]) made of UVB-transparent Plexiglas (Fig. 1). The aquaria were placed in opaque plastic cases covered with UVB-transparent Plexiglas surrounded by a continuous water flow for temperature control $\left(10\right.$ to $\left.14^{\circ} \mathrm{C}\right)$. To reduce the light intensity in the aquaria, strips of black tape were attached to the Plexiglas on top of each box, covering half the area. The tape reduced the irradiance by $70 \%$ (measured at noon, central in the aquarium). After the experiment the walls of the aquaria were inspected and no algal growth was found on them.

The aquaria were initially filled with $40 \mathrm{l}$ of natural surface seawater from the Gullmar fjord, screened through a $160 \mu \mathrm{m}$ net to exclude large grazers. Twice daily (07:00 and 19:00 h) $10 \mathrm{l}$ of water from each aquarium was replaced with seawater filtered through a tangential-flow filter (Minikros, Microgen Inc., Laguna Hills, CA, USA; pore size $0.2 \mu \mathrm{m})$. The added water was a mixture of surface $(90 \%)$ and deep water $(10 \%)$ from the KMRS water system. The water in the aquaria was kept in motion by gentle bubbling.

Each aquarium was randomly given 1 of 4 different treatments (4 replicates for each treatment): (1) NoUVB, shielded from UVBR by a Mylar foil (Mylar-D, DuPont, Wilmington, DE, USA; Fig. 1); (2) $\mathrm{AMB}$, exposed to ambient UVBR $;$ (3) UVB+, exposed for a $10 \%$ increased UVBR; and (4) UVB++, exposed for a $20 \%$ increased UVBR.

Enhanced UVBR was provided by 2 UV-B fluorescent tubes (TL4W/12, Philips, Eindhoven, The Netherlands) placed on the Plexiglas screen covering each UVB+ and UVB++ aquarium. Wavelengths shorter than $290 \mathrm{~nm}$ (UV-C radiation) were screened out by cellulose diacetate film (Erik S. Ekman AB, Stockholm, Sweden;



Fig. 1. Transmittance of Mylar foil, Plexiglas, polyethylene bag, scintillation vial and cellulose diacetate film between 250 and $700 \mathrm{~nm}$. Transmittance was measured on a Shimadzu UV2401PC spectrophotometer
Fig. 1), which was replaced daily. To ensure equal shading effects, dummies for the tube holders were placed on the NoUVB and AMB aquaria. The UVBR intensity was controlled by a computer system linked to a UVBR sensor (International Light SUL 240). The signal from the sensor was continuously transferred to a computer, which, through a digital controlled power supply (Thurlby Thandar Instruments, Huntington, UK), modulated the lamp voltage to desired levels. The applied voltage varied between 2.3 and $6 \mathrm{~V}$. The composition of the lamp spectra was almost independent of the voltage within this range (Fig. 2). The desired levels were determined from the voltage-radiation relation of the lamps determined before the beginning of the experiment. The function of the radiation system was checked continuously by a sensor placed under an additional lamp. The modulation was not totally continuous but had 5 trigger values $\left(0.1,0.4,0.7,1.0\right.$ and $1.3 \mathrm{~W} \mathrm{~m}^{-2}$, ambient UVBR) and was run between 07:00 and 17:00 h. Thus, the enhanced levels given by the UV-B fluorescent tubes (Philips TL4W/12) varied throughout the daily exposure, mirroring the natural UVBR curve. An example of how the enhancement worked is shown in Fig. 3. The 10 and $20 \%$ enhancement levels refer to unweighted UVBR. When weighted with a biological weighting function determined on the marine alga Phaeodactylum tricornutum (Cullen et al. 1992), the enhancement levels were +15 and $+30 \%$, respectively. Daily doses of PAR and UVBR in the aquaria are given in Table 1 . There was some variation among the individual lamps and before the experiment started the efficiency of all lamps was checked and a selection was made, excluding the most deviant ones. After the selection, the coefficient of variation between aquaria was calculated to $15 \%$.

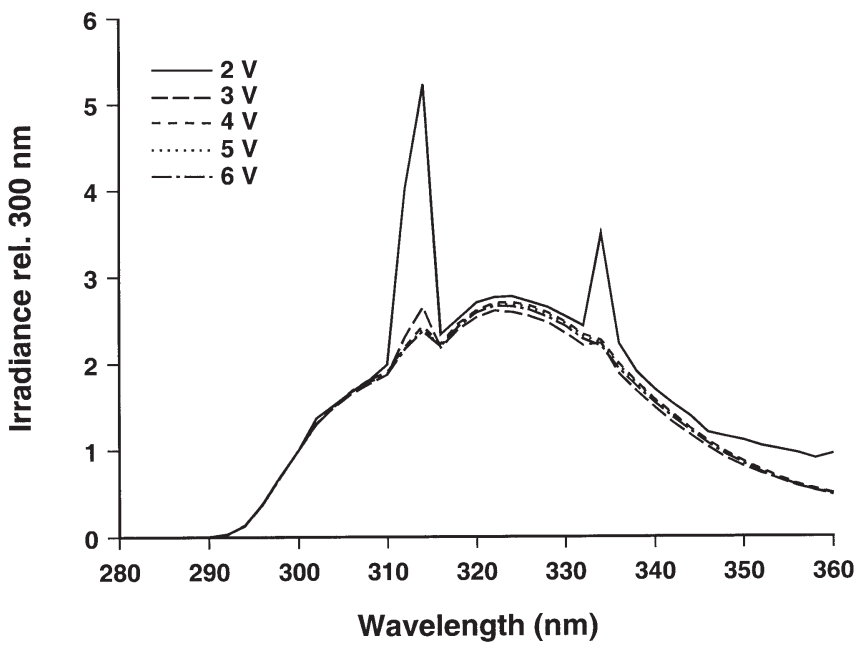

Fig. 2. Lamp spectra depending on applied voltage. The spectra, recorded at noticed voltages, were normalised to 1 at $300 \mathrm{~nm}$ 




Fig. 3. Example of the function of the UV-B radiation (UVBR) exposure system on 13 June 1997 (Day 10). Shown are the radiation levels in the aquaria exposed to ambient UVBR (AMB) and $20 \%$ increased UVBR (UVB++) and the additions from the UV-B lamps

Primary productivity measurements. Primary productivity was measured in separate temperaturecontrolled incubators covered with UV-B-transparent Plexiglas and neutral screens (nylon nets), thus reducing the ambient radiation by $70 \%$. Enhanced UVBR was not used during the productivity measurements. One set of incubators was covered with Mylar foil to exclude UVBR. Primary productivity was measured by a ${ }^{14} \mathrm{C}$-technique to assess 4 different aspects of the primary productivity: total primary productivity, carbon allocation; size-fractionated primary productivity and variation during the day.

The sensitivity to UVBR during the incubation was quantified as the ratio between primary productivity measurements with Mylar screen (NoUVBR) and incubations without a screen (ambient spectra). If the UVBR had any negative effect the ratio was $>1$.

Samples were incubated in polyethylene bags (Whirlpak, Aldrich, Stockholm, Sweden) for size fractionation, while the other samples were incubated in scintillation vials (high quality, Packard Instrument Company Inc., Meriden, CT, USA); transmittances are shown in Fig. 1. When the samples were incubated, $10 \mathrm{ml}$ water was added to each vial and $50 \mathrm{ml}$ to each polyethylene bag.

For total primary productivity $2 \mu \mathrm{Ci}{ }^{14} \mathrm{C}$-bicarbonate was added to each vial, and 3 parallels were placed in each incubator and incubated for $4 \mathrm{~h}$ (approx. 09:00 to $13: 00 \mathrm{~h})$. After the incubation, $300 \mu \mathrm{l}$ formaldehyde (35\%) was added and the samples were acidified with $\mathrm{HCl}$ to $\mathrm{pH}<2$ and bubbled to remove infixed inorganic carbon. Scintillation cocktail (Beckman, Ready Gel) was added and the radioactivity (in disintegrations $\mathrm{min}^{-1}$ ) was measured on a Beckman scintillation counter (Model 1802, Beckman Coulter Inc., Fullerton, CA, USA). For allocation experiments, $5 \mu \mathrm{Ci}^{14} \mathrm{C}$-bicarbonate was added to 3 parallels from each aquarium and incubated at the same time as for total primary productivity but only under ambient radiation. Immediately after the incubation the water was filtered through a nylon filter (Gelman Science, Ann Arbor, MI, USA; $0.2 \mu \mathrm{m}$ ). The filter was placed in a scintillation vial, $0.4 \mathrm{ml}$ distilled water was added, and the filter was refrigerated at $-20^{\circ} \mathrm{C}$ until fractionation. The carbon was fractionated into proteins, LMW compounds, polysaccharides and lipids following the method used by Li et al. (1980). With this fractionation method the LMW fraction includes hydrophilic compounds that are not collected on a glass fibre filter (Whatman GF/F). It contains primarily mono- and oligosaccharides, amino acids and oligopeptides. With the incubation times used in this study more than $80 \%$ of the ${ }^{14} \mathrm{C}$-labelled LMW were carbohydrates (S.A. W. unpubl. data). The lipids were further separated into polar and neutral lipids on silica columns as described by Sundbäck et al. (1997). Total primary productivity and carbon allocation were measured on 4 occasions (Days 0 , 3,6 and 10). All primary productivity measurements included extra samples to which formaldehyde was added before incubation. The values in these were used to correct for abiotic uptake of ${ }^{14} \mathrm{C}$-carbonate.

Table 1. Daily ambient and added radiation doses in the aquaria. nd: not determined; UVB+: $10 \%$ increase in UV-B exposure; UVB++: $20 \%$ increase in UV-B exposure. ${ }^{*}$ Start time 10:00 h

\begin{tabular}{|lccccc|}
\hline Date (1997) & Day & $\begin{array}{c}\text { PAR } \\
\left(\mathrm{mol} \mathrm{photons} \mathrm{m}^{-2}\right)\end{array}$ & $\begin{array}{c}\text { UV-B } \\
\left(\mathrm{KJ} \mathrm{m}^{-2}\right)\end{array}$ & $\begin{array}{c}\text { UV-B addition UVB++ } \\
\left(\mathrm{kJ} \mathrm{m}^{-2}\right)\end{array}$ & $\begin{array}{c}\text { UV-B addition UVB+ } \\
\left.(\mathrm{kJ} \mathrm{m})^{-2}\right)\end{array}$ \\
\hline June 3 & 0 & 12.07 & $\mathrm{nd}$ & $0.37^{*}$ & $0.19^{*}$ \\
June 4 & 1 & 14.46 & $2.98^{*}$ & 0.58 & 0.29 \\
June 5 & 2 & 13.28 & 4.05 & 0.57 & 0.28 \\
June 6 & 3 & 15.92 & 4.15 & 0.64 & 0.32 \\
June 7 & 4 & 14.83 & 4.29 & 0.47 & 0.23 \\
June 8 & 5 & 13.24 & 3.61 & 0.47 & 0.24 \\
June 9 & 6 & 11.30 & 3.42 & 0.48 & 0.33 \\
June 10 & 7 & 14.04 & 3.67 & 0.66 & 0.35 \\
June 11 & 8 & 14.64 & 4.35 & 0.70 & 0.31 \\
June 12 & 9 & 12.54 & 4.37 & 0.62 & \\
June 13 & 10 & & & & \\
\hline
\end{tabular}


For postincubation size fractionation of the primary productivity, $10 \mu \mathrm{Ci}{ }^{14} \mathrm{C}$-bicarbonate was added to each bag and incubated for $4 \mathrm{~h}$ (09:00 to 13:00 h). After incubation $9 \mathrm{ml}$ of the sample was filtered through polycarbonate filters (Poretics Corp., Livermore, CA, USA) with 3 different pore sizes $(0.2,2$ and $10 \mu \mathrm{m})$, and $9 \mathrm{ml}$ was used for measuring total primary productivity. Each filter was washed with $2 \times 1 \mathrm{ml}$ unlabelled seawater and placed in a scintillation vial, scintillation cocktail was added and the radioactivity was measured as above. The radioactivity in the filtrate was measured as for total primary productivity. The recovery of each filtration was calculated as the sum of the radioactivity on filters and filtrate divided by the total. Samples with extreme recoveries ( $>1.5$ or $<0.8$ of the total) were discarded and not used in the calculations ( $22 \%$ of all). The mean recovery of the remaining 84 samples was $1.00 \pm 0.17$. Size fractionation was done on Days 2 and 9.

The daily variation in photosynthetic activity and its sensitivity to ambient UVBR were determined in samples taken from the NoUVB and AMB aquaria on Day 8. Incubations were done as for total primary productivity but for $2 \mathrm{~h}$ only, starting at $08: 00 \mathrm{~h}$, and again at 10:00, 12:00, 14:00 and 16:00 $\mathrm{h}$. The UVBR doses received during the incubations were $0.77,1.53,1.56$ and $0.96 \mathrm{~kJ} \mathrm{~m}^{-2}$, respectively.

Species composition and photosynthetic pigments. Species were counted in water preserved with acid Lugol's solution in sedimentation chambers. For a species to be included in the data set at least 40 cells had to be counted. Cell numbers were transformed to cell volume as in Wängberg et al. (1996b).

For pigment analysis 2 subsamples of $240 \mathrm{ml}$ from each aquarium were gently filtered onto GF/F and immediately frozen in liquid nitrogen. After 3 wk the filters were transferred to a low-temperature freezer $\left(-85^{\circ} \mathrm{C}\right)$ and stored for up to 3 mo until analysed. Two $\mathrm{ml}$ of $100 \%$ methanol was added to the filters and the extraction and HPLC-analysis continued according to Wright \& Jeffrey (1997) using a Linear 206 detector (Spectraphysics, Mountain View, CA, USA). As we were only looking for possible treatment effects, pigments are expressed as ratios to chl a (area/area). Chl a was quantified in $\mu \mathrm{g} \mathrm{l}^{-1}$ as described by Wright \& Jeffrey (1997).

Bacterial productivity. Bacterial productivity was measured using the microcentrifuge ${ }^{3} \mathrm{H}$-leucine incorporation technique (Smith \& Azam 1992). The results were transformed to $\mu \mathrm{g}$ protein $\mathrm{h}^{-1}$ assuming that $7.3 \%$ $(\mathrm{w} / \mathrm{w})$ of the protein is leucine. From each aquarium, 4 samples $(1.2 \mathrm{ml})$ were filled into Eppendorf tubes, $3.33 \mu \mathrm{Ci}{ }^{3} \mathrm{H}$-leucine was added to each sample, and they were incubated for approximately $1 \mathrm{~h}$ in the incubator without Mylar foil (Eppendorf tubes, however, absorb most of the UVBR). The incubations were terminated by adding TCA (5\% final concentration) and the samples were processed according to Smith \& Azam (1992).

Bacterial biomass. Bacterial biomass was estimated as bacterial numbers in formaldehyde-preserved samples using a flow cytometer (FACS Calibur, Becton-Dickinson, Franklin Lakes, NJ, USA) after addition of the DNA stain SYTO-13 (Molecular Probes Inc., Eugene, OR, USA). A standard solution containing fluorescent beads (Fluoresbrite carboxyl YG, Polyscience Inc., Warrington, PN, USA) was used (del Giorgio et al. 1996). The accuracy of the flow cytometer counting was checked by microscopic counting of sample for each measurement session.

Nutrients and DOC. For nutrient analysis of both the added water and the water in the aquaria (sampled before each dilution), the samples were filtered through cellulose acetate filters (Sartorius MiniSart N, $0.45 \mu \mathrm{m}$ ) and stored at $-80^{\circ} \mathrm{C}$ until analysed on an autoanalyser system (Traacs, Bran \& Luebbe Inc., Buffalogrove, IL, USA). Samples for DOC were treated the same way and stored in Pyrex tubes at $-20^{\circ} \mathrm{C}$ until analysis on a TOC-5000 (Shimadzu, Kyoto, Japan) as in Granéli et al. (1996). Both nutrients and DOC were measured in triplicate from each aquarium. The start values (Day 0) were given from 5 replicates taken before the water was distributed to the aquaria.

Statistical analyses. Statistical evaluations were done with ANOVA. Post-hoc analyses were made by the Student-Newman-Keuls test, if necessary, after appropriate transformation. Cochran's test (Winer et al. 1991) was used to check for heterogeneous variances. p < 0.05 was accepted for significant differences.

\section{RESULTS}

\section{General development independent of treatment}

The inorganic nutrient concentrations in the water added to the aquaria showed some irregularity in

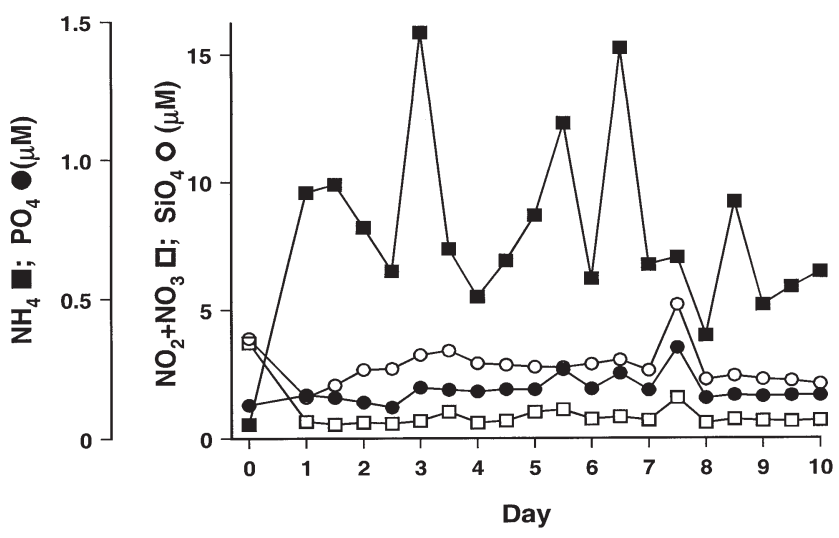

Fig. 4. Nutrient concentration of the water that was used to fill the aquaria. Each value is the mean of 3 replicates 
ammonium concentration but were otherwise low and stable during the experiment (Fig. 4). DOC content was on average $6.5 \pm 0.61 \mathrm{mg} \mathrm{l}^{-1}$ during the first $5 \mathrm{~d}$, increased to $12.6 \pm 1.39 \mathrm{mg} \mathrm{l}^{-1}$ between Days 6 and 8 , and thereafter decreased to initial values.

The ammonium concentrations in the water taken out of the aquaria were significantly higher on Day 3 (407 \pm $26 \mathrm{nM}$ ) than initial values but decreased to very low values on Days 6 and $10(80 \pm 12 \mathrm{nM})$. Nitrate + nitrite concentrations were low on Days 3 and $6(0.44 \pm 0.04 \mu \mathrm{M})$ but increased on Day $10(1.78 \pm 0.39 \mu \mathrm{M})$, while the phosphate concentration was more stable with a mean concentration of $106 \pm 5.1 \mathrm{nM}$ during the whole experiment. The silicate concentration decreased from $2.4 \pm$ $0.01 \mu \mathrm{M}$ on Day 3 to $0.45 \pm 0.01 \mu \mathrm{M}$ on Day 10 . The DOC values increased from Day 0 to Day $3\left(11.1 \pm 1.25 \mathrm{mg} \mathrm{l}^{-1}\right)$ but decreased to $4.8 \pm 0.38 \mathrm{mg} \mathrm{l}^{-1}$ on Days 6 and 10 .

Total algal cell volume (Table 2) and carbon dioxide fixation (Fig. 5) decreased between Day 0 and Day 3 in all treatments but recovered during the experiment to values as high as or higher than initial values. Chl a values dropped significantly from 3.2 to $1.0 \mu \mathrm{g} \mathrm{l^{-1 }}$

Table 2. Cell volumes of microalgae and heterotrophic flagellates $\left(\mu \mathrm{m}^{3} 10^{6} \mathrm{l}^{-1}\right)$. The total cell volume is based on more species than shown. Ciliates are shown as cell numbers. AMB: exposure to ambient UV-B radiation. See Table 1 for other abbreviations

\begin{tabular}{|c|c|c|c|c|c|c|c|c|c|}
\hline & \multirow[t]{2}{*}{ Seed } & \multirow{2}{*}{$\overline{\text { NoUVB }}$} & \multicolumn{2}{|c|}{ Day 3} & \multirow[b]{2}{*}{ UVB++ } & \multirow[b]{2}{*}{ NoUVB } & \multicolumn{2}{|c|}{ - Day 10} & \multirow[b]{2}{*}{ UVB++ } \\
\hline & & & AMB & UVB+ & & & $\mathrm{AMB}$ & UVB+ & \\
\hline \multicolumn{10}{|l|}{ Dinophytes } \\
\hline Ceratium tripos & 19.87 & 10.90 & 16.26 & 11.75 & 22.63 & 0 & 0 & 0 & 2.28 \\
\hline Dinophysis acuminata & 1.10 & 0.24 & 0.24 & 0.71 & 0.55 & 0 & 0 & 0 & 0 \\
\hline Dinophysis norvegica & 0 & 37.48 & 33.13 & 37.57 & 37.84 & 1.63 & 0 & 0 & 0 \\
\hline Gonyaulax grindleyi & 0 & 4.94 & 5.64 & 4.61 & 5.23 & 0 & 0 & 0 & 0 \\
\hline Heterocapsa triquetra & 13.21 & 0.78 & 0.63 & 0.72 & 0.66 & 0 & 0 & 0 & 0 \\
\hline $\begin{array}{l}\text { Pentapharsodinium/ } \\
\text { Scrippsiella sp. }\end{array}$ & 0 & 10.08 & 8.80 & 7.17 & 5.31 & 0 & 0 & 0 & 0 \\
\hline Prorocentrum cf. aporum & 0 & 0 & 0.33 & 0.52 & 0.19 & 0 & 0 & 0 & 0 \\
\hline Prorocentrum micans & 0.58 & 0.30 & 0 & 0 & 0.15 & 0 & 0 & 0 & 0 \\
\hline Protoperidinium sp. & 0 & 4.01 & 0 & 1.46 & 0 & 0 & 0 & 0 & 0 \\
\hline Protoperidinium bipes & 0 & 0 & 0 & 0 & 0 & 1.49 & 1.27 & 0.38 & 1.33 \\
\hline Total $\pm \mathrm{SE}$ & 182.83 & $\begin{array}{c}131.42 \pm \\
10.4\end{array}$ & $\begin{array}{c}101.66 \pm \\
30.9\end{array}$ & $\begin{array}{c}88.25 \pm \\
27.9\end{array}$ & $\begin{array}{c}120.37 \pm \\
23.2\end{array}$ & $\begin{array}{c}3.13 \pm \\
2.5\end{array}$ & $\begin{array}{c}1.27 \pm \\
0.7\end{array}$ & $\begin{array}{c}0.38 \pm \\
0.3\end{array}$ & $\begin{array}{c}3.61 \pm \\
3.6\end{array}$ \\
\hline \multicolumn{10}{|l|}{ Diatoms } \\
\hline Chaetoceros curvisetus & 46.62 & 68.45 & 63.72 & 53.13 & 72.01 & 250.91 & 343.45 & 287.45 & 239.70 \\
\hline Chaetoceros danicus & 50.98 & 60.17 & 49.44 & 49.64 & 50.67 & 133.97 & 130.02 & 98.94 & 92.92 \\
\hline Chaetoceros decipiens & 0 & 0.26 & 0.35 & 0 & 0.39 & 0 & 0.61 & 0 & 0.57 \\
\hline Chaetoceros sp. (solitary) & 1.64 & 0.24 & 0.75 & 0.50 & 0.21 & 2.27 & 3.70 & 2.17 & 2.47 \\
\hline Chaetoceros tenuissimus & 0 & 0 & 0 & 0 & 0 & 136.39 & 122.23 & 119.58 & 166.70 \\
\hline Entomoneis sp. & 0 & 0 & 0 & 0 & 0 & 6.52 & 7.73 & 5.90 & 9.31 \\
\hline Licmophora sp. & 0 & 0 & 0.15 & 0 & 0 & 0.50 & 0 & 0.42 & 0.52 \\
\hline Nitzschia reversa & 0.63 & 0.05 & 0.07 & 0 & 0.05 & 3.72 & 5.69 & 3.61 & 5.77 \\
\hline Pseudonitzschia sp. (solitary) & 0 & 0 & 0 & 0 & 0 & 202.74 & 244.41 & 163.51 & 184.66 \\
\hline Skeletonema costatum & 27.53 & 71.66 & 39.78 & 54.02 & 57.44 & 695.19 & 628.10 & 871.20 & 967.63 \\
\hline Total $\pm \mathrm{SE}$ & 127.40 & $\begin{array}{c}200.83 \pm \\
16.7\end{array}$ & $\begin{array}{c}154.40 \pm \\
10.3\end{array}$ & $\begin{array}{c}157.28 \pm \\
15.9\end{array}$ & $\begin{array}{c}182.04 \pm \\
22.8\end{array}$ & $\begin{array}{c}1432.21 \pm \\
112.3\end{array}$ & $\begin{array}{c}1485.94 \pm \\
125.6\end{array}$ & $\begin{array}{c}1552.78 \pm \\
427.8\end{array}$ & $\begin{array}{c}1670.25 \pm \\
161.4\end{array}$ \\
\hline \multicolumn{10}{|l|}{ Prymnesiophytes } \\
\hline Chrysochromulina sp. & 74.66 & 68.47 & 60.88 & 35.90 & 52.24 & 0 & 0 & 0 & 0 \\
\hline Total \pm SE & 74.66 & $\begin{array}{c}68.47 \pm \\
23.8\end{array}$ & $\begin{array}{c}60.88 \pm \\
21.1\end{array}$ & $\begin{array}{c}35.90 \pm \\
21.4\end{array}$ & $\begin{array}{c}52.24 \pm \\
18.1\end{array}$ & 0 & 0 & 0 & 0 \\
\hline \multicolumn{10}{|l|}{ Cryptophytes } \\
\hline Plagioselmis prolongata & 126.3 & 0 & 0 & 0 & 0 & 0 & 0 & 0 & 0 \\
\hline Teleaulax sp. & 85.6 & 0 & 0 & 0 & 0 & 0 & 0 & 0 & 0 \\
\hline Total $\pm \mathrm{SE}$ & 211.9 & 0 & 0 & 0 & 0 & 0 & 0 & 0 & 0 \\
\hline \multicolumn{10}{|l|}{ Prasinophytes } \\
\hline Micromonas sp. & 0 & 0 & 0 & 0 & 0 & 10.74 & 7.85 & 8.20 & 13.21 \\
\hline Nephroselmis sp. & 0 & 0 & 0 & 0 & 0 & 10.08 & 6.84 & 5.24 & 7.16 \\
\hline Total $\pm \mathrm{SE}$ & 0 & 0 & 0 & 0 & 0 & $\begin{array}{c}20.83 \pm \\
6.3\end{array}$ & $\begin{array}{c}14.69 \pm \\
5.8\end{array}$ & $\begin{array}{c}13.44 \pm \\
5.5\end{array}$ & $\begin{array}{c}20.37 \pm \\
5.9\end{array}$ \\
\hline Total algal cell volume & 597 & $\begin{array}{l}401 \pm \\
31.7\end{array}$ & $\begin{array}{c}377 \pm \\
54\end{array}$ & $\begin{array}{c}335 \pm \\
23.7\end{array}$ & $\begin{array}{c}348 \pm \\
15.3\end{array}$ & $\begin{array}{c}1456 \pm \\
112.4\end{array}$ & $\begin{array}{c}1502 \pm \\
124.3\end{array}$ & $\begin{array}{c}1567 \pm \\
161.7\end{array}$ & $\begin{array}{c}1694 \pm \\
156\end{array}$ \\
\hline Ciliates & 34601 & $\begin{array}{c}2947 \pm \\
943\end{array}$ & $\begin{array}{c}3501 \pm \\
164\end{array}$ & $\begin{array}{c}3082 \pm \\
24\end{array}$ & $\begin{array}{c}3274 \pm \\
240\end{array}$ & $\begin{array}{c}472 \pm \\
112\end{array}$ & $\begin{array}{c}515 \pm \\
124\end{array}$ & $\begin{array}{c}519 \pm \\
162\end{array}$ & $\begin{array}{c}748 \pm \\
156\end{array}$ \\
\hline
\end{tabular}



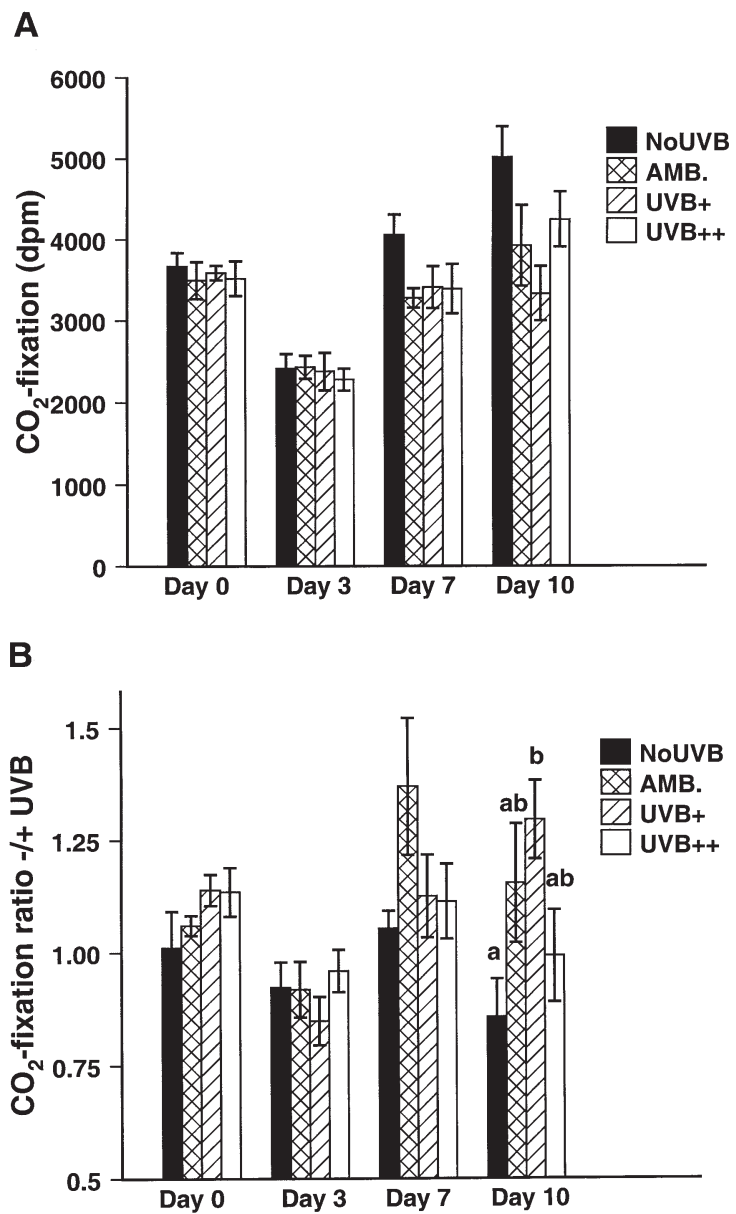

Fig. 5. Primary productivity (incorporation of ${ }^{14} \mathrm{C}$-bicarbonate over $4 \mathrm{~h}$ ). All experiments were done in incubators where the ambient radiation was reduced by $70 \%$. Error bars indicate SE $(n=4)$. Significant differences between treatments are indicated by labels over the bar. Different labels indicate a significant difference. (A) Productivity in ambient radiation, including UVBR; $(\mathrm{B})$ ratio of productivity without UVB to productivity with UVBR

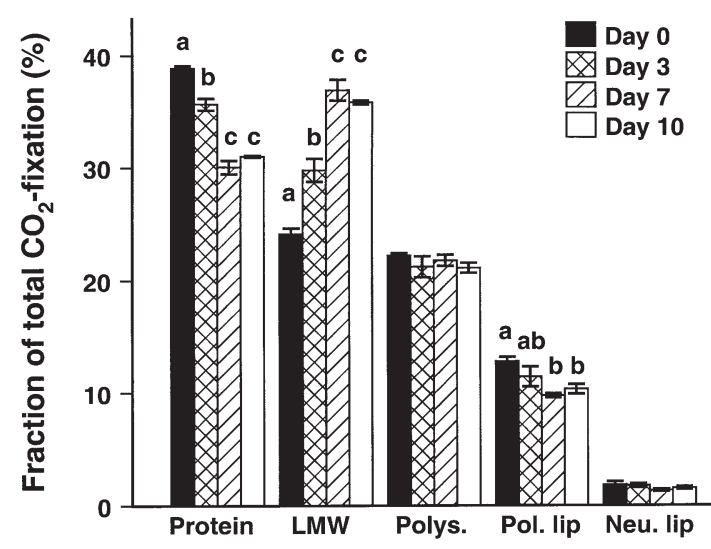

Fig. 6. Allocation of carbon to different biochemical classes (percentage of total carbon fixation). Four hour incubations in ambient radiation reduced by $70 \%$. Values are mean for all treatments. Error bars represent SE $(n=16)$. Significant differences between treatments are indicated by labels over the bar. Different labels indicate a significant difference. LMW: low molecular weight compounds; Neu. lip.: neutral lipids; Pol. lip.: polar lipids; Polys.: polysaccharides

between Day 0 and 3 and stabilised around $1.0 \mu \mathrm{g} \mathrm{l}^{-1}$ throughout the experiment (Table 3).

The pattern of carbon allocation changed slightly during the experiment with a significant decrease in the fraction allocated to proteins and polar lipids and an increased allocation to LMW compounds (Fig. 6).

According to total cell volume the initial proportions of different phytoplankton groups were 16, 52 and $30 \%$ for dinoflagellates, diatoms and prymnesiophytes, respectively (Table 2). In general, the cell counts were confirmed by the pigment concentrations where peridinin and fucoxanthin initially showed high ratios to chl a (Table 3). From Day 3 onwards the pigment ratios decreased significantly for the pigments peridinin, 19'-

Table 3. Chlorophylls (Chl) and carotenoids (ratios to chl a) in the different treatments. Values are based on 2 samples from the 4 replicate mesocosms, respectively. ALLO: alloxanthin; $\beta$ CAR: $\beta$-carotene; DDX: diadinoxanthin; DIAT: diatoxanthin; FUCO: fucoxanthin; HEX: 19'-heaxanoyloxyfucoxanthin; PERI: peridinin; ZEA: zeaxanthin

\begin{tabular}{|c|c|c|c|c|c|c|c|c|c|c|c|c|c|c|c|c|}
\hline & \multicolumn{4}{|c|}{ Day 0} & \multicolumn{4}{|c|}{ Day 3} & \multicolumn{4}{|c|}{ Day 7} & \multicolumn{4}{|c|}{ Day 10} \\
\hline & NoUVB & $\mathrm{AMB}$ & UVB+ & UVB++ & NoUVB & AMB & UVB+ & UVB++ & NoUVB & AMB & UVB+ & UVB++ & NoUVB & AMB & UVB+ & UVB++ \\
\hline Chl a $\left(\mu g \mathrm{l}^{-1}\right)$ & 1) 3.048 & 3.114 & 2.948 & 2.972 & 0.920 & 0.924 & 0.756 & 0.994 & 1.1594 & 1.020 & 0.944 & 1.000 & 0.987 & 0.918 & 0.835 & 0.880 \\
\hline Chl $b$ & 0.022 & 0.016 & 0.019 & 0.021 & 0 & & 0 & 0 & 0 & 0 & 0 & 0 & 0 & 0 & 0 & 0 \\
\hline Chl $c 1+c 2$ & 0.451 & 0.445 & 0.451 & 0.455 & 0.487 & 0.478 & 0.494 & 0.460 & 0.509 & 0.476 & 0.575 & 0.595 & 0.678 & 0.745 & 0.784 & 0.681 \\
\hline Chl $c 3$ & 0.115 & 0.107 & 0.106 & 0.107 & 0.063 & 0.097 & 0.100 & 0.096 & 0.065 & 0.070 & 0.073 & 0.079 & 0.141 & 0.093 & 0.116 & 0.120 \\
\hline HEX & 0.149 & 0.146 & 0.146 & 0.148 & 0.114 & 0.113 & 0.114 & 0.113 & 0.014 & 0.008 & 0.008 & 0.009 & 0.012 & 0 & 0 & 0 \\
\hline ALLO & 0.412 & 0.408 & 0.431 & 0.404 & 0.260 & 0.252 & 0.262 & 0.277 & 0 & 0 & 0 & 0 & 0 & 0 & 0 & 0 \\
\hline$\beta C A R$ & 0.037 & 0.026 & 0.029 & 0.035 & 0.110 & 0.075 & 0.037 & 0.051 & 0.088 & 0.076 & 0.066 & 0.064 & 0.082 & 0.043 & 0.072 & 0.080 \\
\hline DDX+ DIAT & Г 0.315 & 0.318 & 0.333 & 0.337 & 0.408 & 0.441 & 0.415 & 0.419 & 0.359 & 0.332 & 0.343 & 0.378 & 0.641 & 0.630 & 0.579 & 0.581 \\
\hline FUCO & 0.385 & 0.370 & 0.383 & 0.385 & 0.499 & 0.519 & 0.544 & 0.488 & 0.728 & 0.658 & 0.728 & 0.746 & 0.724 & 0.745 & 0.737 & 0.679 \\
\hline PERI & 0.075 & 0.074 & 0.075 & 0.076 & 0.008 & 0.017 & 0.011 & 0.016 & 0 & 0 & 0 & 0 & 0 & 0 & 0 & 0 \\
\hline ZEA & 0.003 & 0.010 & 0 & 0 & 0 & 0 & 0 & 0 & 0.006 & 0.008 & 0.007 & 0 & 0 & 0.014 & 0 & 0 \\
\hline
\end{tabular}


Table 4. Summary of effects of UV-B radiation (UVBR) on all variables studied. +: significant effects $(\mathrm{p}<0.05, \mathrm{n}=4) ;-$ : non-significant effects; $n d$ : not determined

\begin{tabular}{|lccc|}
\hline & Day 3 & Day 7 & Day 10 \\
\hline Microalgal biomass & - & nd & - \\
Microalgal composition & - & nd & + \\
Photosynthetic pigments & - & - & - \\
Primary productivity & & & - \\
Total productivity & - & - & + \\
Ratio in productivity \pm UVBR & - & nd & $+{ }^{\text {b }}$ \\
Size fractionation of productivity & $+^{\mathrm{a}}$ & + & - \\
Carbon allocation & + & - & - \\
Bacterial biomass & - & nd & - \\
Bacterial productivity & nd & - & - \\
Nutrients and DOC & - & & \\
a Day 2; ${ }^{b}$ Day 9 & & & \\
\hline
\end{tabular}

was larger in the AMB than in the NoUVB communities. This shows that the AMB communities were more sensitive to UVBR during the incubation than the NoUVB communities (Fig. 7B).

At the beginning of the experiment (Day 2), a smaller fraction of the fixed carbon was retained on the $10 \mu \mathrm{m}$ filter in the UVB++ treatment than in the other treatments. Later in the experiment (Day 9), algae >10 $\mu$ m fixed relatively more carbon in the AMB treatment than in either the UVB+ or the UVB++ (Fig. 8).

The fraction allocated to polysaccharides was significantly affected by the hexanoyloxyfucoxanthin, alloxanthin and chl $b$, indicating a shift in the microalgal community composition. Furthermore, chl $c 1+c 2$, fucoxanthin and diadinoxanthin increased significantly, indicating a dominance of diatoms, which was confirmed by the algal counts. The cell counts also showed that the small prasinophytes Micromonas sp. and Nephroselmis sp. appeared in the latter part of the experiment; this was not, however, confirmed by the pigment ratios.

The bacterial cell numbers decreased from $2.0 \times 10^{6}$ to $1.0 \times 10^{6}$ cells $\mathrm{l}^{-1}$ between Day 0 and Day 3 and continued to decrease to $0.5 \times 10^{6}$ cells $l^{-1}$ on Day 10 . In contrast to carbon dioxide fixation, bacterial protein production increased from $17.2 \pm 1.1 \mathrm{ng} \mathrm{l}^{-1} \mathrm{~h}^{-1}$ at the start to $114.3 \pm 14.8$ on Day 10 despite decreased bacterial cell numbers.

\section{Effects of UVBR}

Parameters significantly affected by the UVBR treatment are shown in Table 4.

With incubation under ambient radiation, the primary productivity, as the amount of chl $a$, was higher in the NoUVB treatment than the other treatments at the end of the experiment (not significant, $\mathrm{p}=0.073$ on Day 10) (Fig. 5A). The ratio of primary productivity without to primary productivity with UVBR on Day 10 was significantly larger in the UVB+ than in the NoUVB treatment (Fig. 5B). This indicates that the primary productivity in UVB+ was more sensitive than NoUVB to ambient UVBR during the incubation.

In the diurnal variation study on Day 8, significantly more carbon was fixed by the NoUVB communities than the $\mathrm{AMB}$ when incubated under ambient radiation starting at 10:00, 14:00 and 16:00 $\mathrm{h}$ (Fig. 7A). In the incubations started at 10:00 $\mathrm{h}$, the ratio, in primary productivity, of incubations done with to those done without UVBR

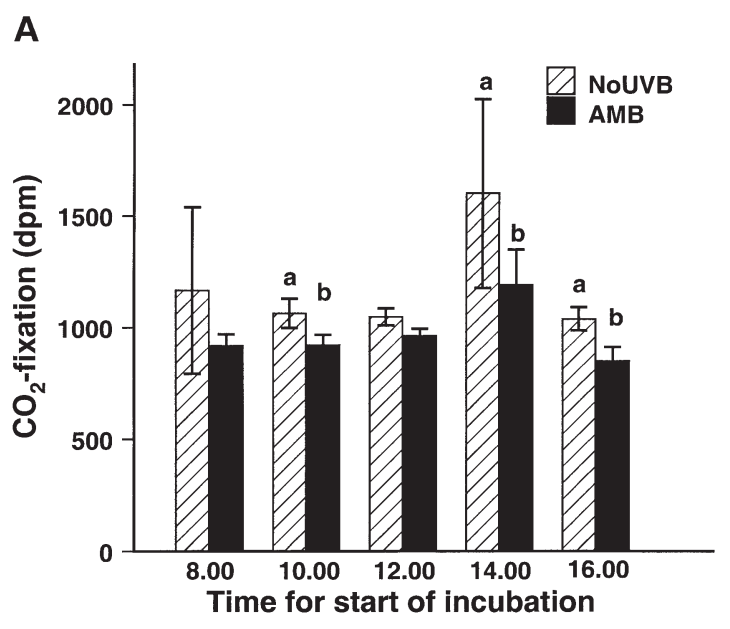

B

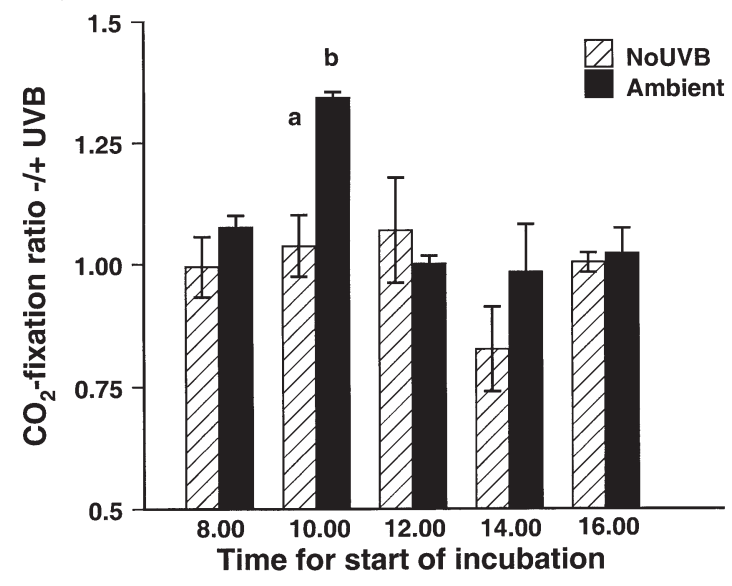

Fig. 7. Primary productivity (incorporation of ${ }^{14} \mathrm{C}$-bicarbonate over $2 \mathrm{~h}$ ) at different times of the day. Ambient radiation reduced by $70 \%$ (with or without UV-B). Error bars represent $\mathrm{SE}(\mathrm{n}=4)$. Significant differences between treatments are indicated by labels over the bar. Different labels indicate a significant difference. (A) Productivity in ambient radiation, including $\mathrm{UVBR}_{\text {; }}(\mathrm{B})$ ratio of productivity without UVBR to productivity with UVBR 




B

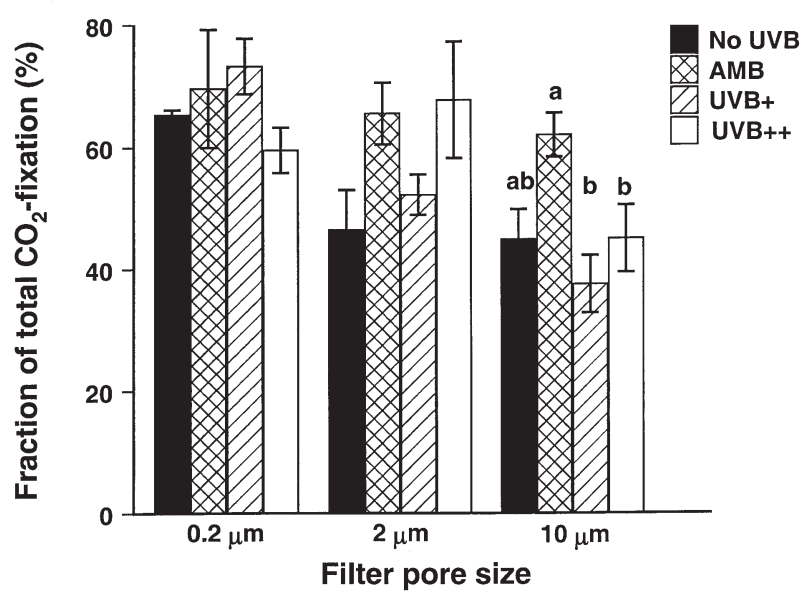

Fig. 8. Fraction of total carbon fixation retained on filters with different pore sizes. Four hour incubations in ambient radiation reduced by $70 \%$. Error bars represent SE (n=4). Significant differences between treatments are indicated by labels over the bar. Different labels indicate a significant difference.

(A) Day 2; (B) Day 9

UVBR treatment on Days 3 and 7 , but in different ways. On Day 3, a smaller fraction was allocated to polysaccharides in the NoUVB treatment than in either the UVB+ or the UVB++ treatments, while on Day 6 more carbon was allocated to polysaccharides in the NoUVB treatment than in the AMB and UVB++ treatments (Fig. 9).

A significant treatment effect was found in the species composition on Day 10 (Table 2). Two species, Pseudonitzschia sp. and Nitzschia reversa, were significantly affected by the UVBR treatments. For Pseudonitzschia sp. a significantly $(\mathrm{p}<0.007)$ higher cell volume was found in AMB than in any of the other treatments. The same pattern was found for $N$. reversa but because of non-homogeneous variance it was not possible to include UVB++ in the statistical analysis.



Fig 9. Percentage of total fixed carbon allocated to polysaccharides. Four hour incubations in ambient radiation reduced by $70 \%$. Error bars represent SE $(\mathrm{n}=4)$. Significant differences between treatments are indicated by labels over the bar. Different labels indicate a significant difference

No significant treatment effects were found for algal and bacterial biomass, composition of photosynthetic pigments and bacterial leucine incorporation. No significant UVBR effects were found for concentrations of inorganic nutrients or DOC. There was, however, a strong tendency to higher phosphate concentrations in the NoUVB treatment on Day $10(\mathrm{p}=0.053)$.

\section{DISCUSSION}

\section{Relevance of exposure levels}

This study was designed to determine the effects that a reduction in the stratospheric ozone layer would have on natural microbial communities in temperate latitudes. By allowing the ambient radiation to modulate the addition of UVBR, the ratio of UVBR to other wavelengths was retained. When the weighted intensities and a radiation amplification factor of 1.6 (calculated for a generalised plant spectrum [Caldwell et al. 1986] in Madronich 1993) were used, the 2 enhancement levels corresponded to a $19 \%$ and $9 \%$ reduction of the ozone layer. The TOMS data for May to August 1997 and 1998 at the location of the experiment showed that episodes with more than $9 \%$ reduction from the mean DU levels (353 DU) were found during $15 \%$ of the days, but during $1 \mathrm{~d}$ only, the reduction increased by $19 \%$. The UVB+ level is thus relevant for short-term episodes of a reduced ozone layer during summertime. If the 1997-98 data are compared with the mean 1979-80 value (362 DU), there was a >9\% reduction during $>20 \%$ of the days and a $19 \%$ reduction during $>4 \%$ of the days. The UVB++ level is thus representative of the highest levels of reduction due to the long-term decline, to date, in stratospheric ozone, 
thus becoming more relevant as the thinning of the ozone layer continues. As the UVBR effects at the water surface, despite being the strongest, are not representative of the whole water column, and primary productivity is inhibited by PAR and UVAR at the surface on sunny days, we reduced the ambient radiation by $70 \%$ using a neutral screen. As the attenuation in the water is not uniform within the PAR-UV range an unavoidable consequence is that the depth to which this reduction corresponds is wavelength dependent.

To obtain a realistic enhancement of UVBR, we developed a computer-modulated UVBR exposure system, where the intensity of the enhanced radiation was directly related to the ambient UVBR, important for keeping realistic ratios of UVBR to other wavelengths. Similar techniques have earlier been used in terrestrial experiments (McLeod 1997 and references therein).

\section{Set-up of the model ecosystems}

In their natural environment phytoplankton can have a high net production rate but grazing keeps the standing stock more or less constant (though under a high turnover rate). In small-scale experimental systems the grazing pressure usually becomes too low, the phytoplankton standing stock increases, and the turnover rate declines. To avoid this problem, we diluted the community semicontinuously to keep a high net growth and succession rate without increasing the standing stock. Through this dilution, less than $1 \%$ of the organisms in the seed community would remain at the end of the experiment, which gives species favoured by conditions in the aquaria (including different degrees of UVBR) good opportunities to increase. The selection pressure also induced a succession independent of the differences in UVBR exposure including relative increase in diatoms, increased leucine uptake per bacterial cell and reduced chl a values.

\section{Treatment effects}

The results show that ambient UVBR affects marine plankton communities, not only in surface water but also down to substantial parts of the euphotic zone, and that it is affected by the present levels of ozone reduction. The effects were not dramatic and included no changes in biomass or total productivity of either phytoplankton or bacteria. The effects were instead found on phytoplankton species composition, sizefractionated primary productivity, carbon allocation and the sensitivity to ambient UVBR in primary productivity. Also Laurion et al. (1998) and Mostajir et al. (1999) found that the total phytoplankton biomass was not affected by enhanced UVBR, but changed structurally, although the UVBR exposure level in these experiments was much higher than ours. To evaluate fully the ecological significance of the results from the present study, not only should the experiment be replicated elsewhere, but also it is essential to include more trophic levels to gain knowledge about possible negative consequences on the whole ecosystem.

That carbon dioxide fixation of communities developed under UVBR exposure were more sensitive to UVBR than communities shielded from UVBR was also found in similar experiments performed in the Southern Ocean (Wängberg \& Wulff unpubl. data) where the increased sensitivity was even more pronounced. We hypothesise that this was an adaptive process that functions as follows: communities developed under UVBR that partially inhibit some process or component build up an over-capacity to compensate for the loss. When the community is instead shielded from UVBR, the over-capacity results in increased carbon dioxide fixation. Potential photosynthetic processes are, for example, the carbon dioxide fixation protein RUBISCO or components in the chloroplastic electron transport, both of which are known to be sensitive to UVBR (Vincent \& Roy 1993, Strid et al. 1994).

This hypothesis presumes that the over-capacity is built up each night, through either repair or new synthesis, but successively gets reduced each day on UVBR exposure. That the UVBR-induced damages are compensated during the night is supported by the significant difference in sensitivity between NoUVB and AMB treatments at 10:00 $\mathrm{h}$, before the communities had been exposed to high UVBR, but not when the incubation was started at 12:00 h (Fig. 7B). Differences in sensitivity to UVBR depending on the time of day was earlier shown by Prezelin et al. (1994), with the lowest inhibition found in the middle of the day when the UVBR to (UVR + PAR) ratio was highest. They suggested that the reduced sensitivity in the middle of the day is due to a protective mechanism induced during the morning. This cannot be the case in our experiment, as the tolerance was not enhanced when incubations were started at 12:00 h. An increased sensitivity to UVBR in the primary productivity of communities when exposed to UVBR questions the use of short-term primary productivity measurements to predict the ecological consequences of UVBR.

We found that communities developed under enhanced UVBR had a smaller part of the carbon dioxide fixation in the largest fraction $(>10 \mu \mathrm{m})$. Our data support the data published by Mostajir et al. (1999) and Wängberg et al. (1996b), which show that smaller phytoplankton are favoured by UVBR, in contrast to the data of Laurion et al. (1998). The agreement between the data presented here and in those of 
Wängberg et al. (1996b) might depend on the fact that both experiments were marine and went through the same type of succession from dinoflagellates to diatoms. In contrast, the succession described by Laurion et al. (1998) was limnic and towards an increase in the proportion of picocyanobacteria.

As the incubations before filtration in our experiment lasted $4 \mathrm{~h}$, there is a risk that carbon fixed by small algae that are grazed on during the incubation were retrieved in the wrong size class. We could not estimate this risk. The lack of effects on ciliate cell numbers indicates, however, that a possible effect was treatment independent. Thus it should not have affected the differences found between treatments.

As in Wängberg et al. (1998) a UVBR-mediated increase in the fraction allocated to polysaccharides was balanced with a decreased allocation to LMW compounds at the beginning of the experiment. On Day 7 , the pigment composition indicated that diatoms dominated the communities, and the fraction allocated to polysaccharides was decreased by the UVBR treatment as in the diatom-dominated microbenthic communities reported by Sundbäck et al. (1997). It is not possible to say whether these changes between the early and later parts of the experiment were due to different species or whether it was a physiological response to the UVBR exposure. Our incubations for measuring carbon allocation were all done under ambient radiation with the aim to study the long-term changes in carbon metabolism. Goes et al. (1996) have shown that UV radiation (UV-A + UV-B) has an acute effect on carbon allocation in diatom-dominated phytoplankton communities. They found that UV radiation inhibited the synthesis of storage carbohydrates that were easily hydrolysed but not of the more stable structural carbohydrates. Their fractionation procedure differs from ours but agrees with our results in the early part of the experiments.

In the present study, the only species affected by UVBR were the pennate diatoms Pseudonitzschia sp. and Nitzschia reversa, both belonging to Biraphidae. Our findings agree with those of Karentz et al. (1991), who found that the pennate diatom Nitzschia kerguelensis was more sensitive than the centric diatoms to UVBR, a difference that may be explained by differences in morphology (cell shape, chloroplasts) as well as habitat.

That the effects of UVBR on development of microbial communities depend on the nutrient condition was clearly shown in microbenthic communities by Wulff et al. (2000), where addition of nutrients $(\mathrm{P}, \mathrm{N}$ and $\mathrm{Si}$ ) reduced the UVBR effects. We found no effects on concentration of dissolved nutrients at the $\mathrm{p}<0.05$ level, but a tendency was found for phosphate on Day 10, with lower concentrations in all UVBR-exposed communities than in AMB. If the NoUVB is compared with all the UVBR-exposed communities, the effect is significant $(p=0.005)$. This was probably due to a larger uptake of phosphate, as we do not know any way in which UVBR directly can reduce the phosphate concentration. Interestingly, several other studies have indicated that the demand for phosphate is increased by UV-B exposure (Hessen et al.1995, Wängberg et al. 1998, Wängberg et al. 1999).

\section{CONCLUSIONS}

From this 10 day experiment to assess the effects of ambient and enhanced UVBR on marine microbial communities on the Swedish west coast we reached the following conclusions:

- Ambient UVBR does not directly threaten the phytoplankton or bacterial biomass in pelagic water, nor does the enhancement in UVBR that has occurred following short- and long-term reductions in stratospheric ozone. - Ambient and enhanced UVBR, however, induce several changes within the phytoplankton community, including changes in carbon allocation, size distribution and species composition, that might change the ecological interactions between phytoplankton and other parts of the marine food web.

- UVBR exposure during the development of phytoplankton communities changes their sensitivity to UVBR in short-term carbon dioxide fixation measurements.

Acknowledgements. We thank Kristineberg Marine Research Station for providing excellent working facilities. We also thank Wilhelm Granéli and colleagues at the Limnological Institute in Lund University for help with the DOC measurements. Financial support was provided by research grants from the Swedish Environmental Protection Agency, the Swedish Natural Science Research Council, and the Swedish Council for Planning and Coordination of Research. Additional support was given by funds from Hierta-Retzius, Wilhelm and Martina Lundgren, Captain Carl Stenholm and Helge Ax:son Johnson.

\section{LITERATURE CITED}

Arts MT, Rai H (1997) Effects of enhanced ultraviolet-B radiation on the production of lipid, polysaccharide and protein in three freshwater algal species. Freshw Biol 38:597-610

Bothwell ML, Sherbot D, Roberge AC, Daley RJ (1993) Influence of natural ultraviolet radiation on lotic periphytic diatom community growth, biomass accrual, and species composition: short-term versus long-term effects. J Phycol 29:24-35

Bothwell ML, Sherbot DMJ, Pollock CM (1994) Ecosystem response to solar ultraviolet-B radiation: influence of trophic-level interactions. Science 265:97-100

Bushaw KL, Zepp RG, Tarr MA, Schulz-Jander D, Bourbonniere RA, Hodson RE, Miller WL, Bronk DA, Moran MA (1996) Photochemical release of biologically available nitrogen from dissolved organic matter. Nature 381:404-407 
Cabrera S, López M, Tartarotti B (1997) Phytoplankton and zooplankton response to ultraviolet radiation in a highaltitude Andean lake: short- versus long-term effects. J Plankton Res 19:1565-1582

Caldwell MM, Camp LB, Warner CW, Flint SD (1986) Action spectra and their key role in assessing biological consequences of solar UV-B radiation changes. In: Worrest RC, Caldwell MM (eds) Stratospheric ozone reduction. Solar ultraviolet radiation and plant life. Springer Verlag, Berlin, p 113-124

Cullen JJ, Neale PJ, Lesser MP (1992) Biological weighting function for the inhibition of phytoplankton photosynthesis by ultraviolet radiation. Science 258:646-650

Davidson AT (1998) The impact of UVB radiation on marine plankton. Mutat Res 422:119-129

del Giorgio PA, Bird DF, Prairie YT, Planas D (1996) Flow cytometric determination of bacterial abundance in lake plankton with the green nucleic stain SYTO 13. Limnol Oceanogr 41:783-789

Franklin LA, Forster RM (1997) The changing irradiance environment: consequences for marine macrophyte physiology, productivity and ecology. Eur J Phycol 32:207-232

Goes JI, Handa N, Taguchi S, Hama T, Saito H (1996) Metabolism of neutral monosaccharide constituents of storage and structural carbohydrates in natural assemblages of marine phytoplankton exposed to ultraviolet radiation. Limnol Oceanogr 41:1478-1489

Granéli W, Lindell M, Tranvik L (1996) Photo-oxidation production of dissolved inorganic carbon in lakes of different humic content. Limnol Oceanogr 41:698-706

Gustavson K, Garde K, Wängberg SÅ, Selmer JS (2000) The impact of UV-B radiation on bacterial activity in coastal waters. J Plankton Res 22:1501-1511

Hessen DO, van Donk E, Andersen T (1995) Growth responses, P-uptake and loss of flagellae in Chlamydomonas reinhardtii exposed to UV-B. J Plankton Res 17:17-27

Karentz D (1994) Ultraviolet tolerance mechanisms in Antarctic marine organisms. In: Weiler CS, Penhale PA (eds) Ultraviolet radiation in Antarctica: measurements and biological effects. Antarct Res Ser 62:93-110

Karentz D, Cleaver JE, Mitchell DL (1991) Cell survival characteristics and molecular responses of antarctic phytoplankton to ultraviolet-B radiation. J Phycol 27:326-341

Karentz D, Bothwell ML, Coffin RB, Hanson A, Herndl GJ, Kilham SS, Lesser MP, Lindell M, Moeller RE, Morris DP, Neale PJ, Sanders RW, Weiler CS, Wetzel RG (1994) Impact of UV-B radiation on pelagic freshwater ecosystems: report of working group on bacteria and phytoplankton. Arch Hydrobiol Beih 43:31-69

Keller AA, Hargraves P, Jeon H, Klein-MacPhee G, Klos E, Oviatt C, Zhang J (1997) Effects of ultraviolet-B enhancement on marine trophic levels in a stratified coastal system. Mar Biol 130:277-287

Laurion I, Lean DRS, Vincent WF (1998) UVB effects on a plankton community: results from a large-scale enclosure assay. Aquat Microb Ecol 16:189-198

Li WKW, Glover HE, Morris I (1980) Physiology of carbon photoassimilation by Oscillatoria thiebautii in the Caribbean sea. Limnol Oceanogr 25:447-456

Madronich S (1993) The atmosphere and UV-B radiation at ground level. In: Young AR, Björn LO, Moan J, Nultsch W (eds) Environmental UV photobiology. Plenum Press, New York, p 1-40

McLeod AR (1997) Outdoor supplementation systems for studies of the effects of increased UV-B radiation. Plant Ecol 128:78-92

Mitchell DL, Karentz D (1993) The induction and repair of DNA photodamage in the environment. In: Young AR, Björn LO, Moan J, Nultsch W (eds) Environmental UV photobiology. Plenum Press, New York, p 345-377
Moroz AL, Ehrman JM, Clair TA, Gordon RJ, Kaczmarska I (1999) The impact of ultraviolet-B radiation on the motility of the freshwater epipelic diatom Nitzschia linearis. Global Change Biol 5:191-199

Mostajir B, Demers S, deMora S, Belzile C, Chanut JP, Gosselin M, Roy S, Villegas PZ, Fauchot J, Bouchard J, Bird D, Monfort P, Levasseur M (1999) Experimental test of the effect of ultraviolet-B radiation in a planktonic community. Limnol Oceanogr 44:586-596

Odmark S, Wängberg SÅ, Sundbäck K, Wulff A, Nilsson C (1998) Effects of UVB radiation on shallow-water marine microbenthic communities from a sandy sediment. Mar Biol 132:335-345

Prezelin BB, Boucher NP, Smith RC (1994) Marine primary production under the influence of the Antarctic ozone hole: icecolors '90. In: Weiler CS, Penhale PA (eds) Ultraviolet radiation in Antarctica: measurements and biological effects. Antarct Res Ser 62:159-186

Smith DC, Azam F (1992) A simple economical method for measuring bacterial protein synthesis rates in seawater using 3H-leucine. Mar Microb Food Webs 6:107-114

Strid Å, Chow WS, Anderson JM (1994) UV-B damage and protection at the molecular level in plants. Photosynth Res 39:475-489

Sundbäck K, Odmark S, Wulff A, Nilsson C, Wängberg SÅ (1997) Effects of enhanced UV-B radiation on a marine benthic diatom mat. Mar Biol 128:171-179

Vincent WF, Roy S (1993) Solar ultraviolet-B radiation and aquatic primary production: damage, protection, and recovery. Environ Rev 1:1-12

Wängberg SÅ, Selmer JS (1997) Mesocosm studies on the effects of UV radiation in marine ecosystems. In: Häder DP (ed) Effects of ozone depletion in aquatic ecosystems. Academic Press, Austin, p 199-214

Wängberg SÅ, Selmer JS, Ekelund N, Gustavson K (1996a) Effects of increased UV-B radiation on the nordic marine ecosystem: a literature review. Nordic Council of Ministers TemaNord 515, Copenhagen

Wängberg SÅ, Selmer JS, Gustavson K (1996b) Effects of UV$B$ radiation on biomass and composition in marine phytoplankton communities. In: Figueroa FL, Jiménez C, PérezLloréns JL, Niell FX (eds) Underwater light and algal photobiology. Sci Mar (Barc) 60(Suppl 1):81-88

Wängberg SÅ, Selmer JS, Gustavson K (1998) Effects of UV-B radiation on carbon and nitrogen dynamics in marine planktonic communities. J Photochem Photobiol B 45:19-24

Wängberg SÅ, Garde K, Gustavson K, Selmer JS (1999) Effects of UV-B radiation on marine phytoplankton communities. J Plankton Res 21:147-166

Wetzel RG, Hatcher PG, Bianchi TS (1995) Natural photolysis by ultraviolet irradiance of recalcitrant dissolved organic matter to simple substrates for rapid bacterial metabolism. Limnol Oceanogr 40:1369-1380

Winer BJ, Brown DR, Michels KM (1991) Statistical principles in experimental design. McGraw-Hill Inc, New York

Worrest RC, Thomson BE, van Dyke H (1981) Impact of UV-B radiation upon estaurine microcosms. Photochem Photobiol 33:861-867

Wright SW, Jeffrey SW (1997) High-resolution HPLC system for chlorophylls and carotenoids of marine phytoplankton. In: Jeffrey SW, Mantoura RFC, Wright SW (eds) Phytoplankton pigments in oceanography. UNESCO Publishing, Paris, p $327-360$

Wulff A, Nilsson C, Sundbäck K, Wängberg SÅ, Odmark S (1999) UV radiation effects on microbenthos: a four month field experiment. Aquat Microb Ecol 19:269-278

Wulff A, Wängberg SÅ, Sundbäck K, Nilsson C, Underwood GJC (2000) Effects of UVB radiation on a marine microphytobenthic community growing on a sand-substratum under different nutrient conditions. Limnol Oceanogr 45:1144-1152 